\title{
Policy options for, and constraints on, effective adaptation for rivers and wetlands in northeast Queensland
}

\author{
Henry. Boer. Centre for Governance and Public Policy, Griffith University, Nathan \\ Queensland 4111.
}

Email: h.boer@griffith.edu.au.

Developing and implementing effective adaptation policies for freshwater and estuarine systems in Australia will be a significant challenge in a rapidly changing climate. The broad aims of climate change adaptation policies are to reduce vulnerability and increase the adaptive capacity and resilience of ecosystems to climate change impacts. There are a range of adaptation policy options relevant to aquatic systems, and many of these measures can be 'mainstreamed' or incorporated into existing conservation and resource management frameworks. This article evaluates adaptation policy options and the constraints on policy implementation for freshwater and estuarine ecosystems in the coastal floodplains of tropical Queensland. Many of these aquatic systems are in a degraded condition and are vulnerable to the compounded impacts of climate change and other stressors. The analysis suggests that statutory planning schemes, water resource planning and protected area frameworks provide limited scope to address the more severe threats to these systems from rising sea levels, extreme cyclones, floods and droughts. In many locations, the effectiveness of adaptation policies is constrained by existing land uses and competing demands from communities and industry sectors. To prevent further widespread loss of habitat may require the development and implementation of new policies that prioritise adaptation management for freshwater and estuarine ecosystems.

Keywords: climate change, adaptation policies, rivers, wetland ecosystems

Adapting to the impacts of climate change in the coastal zone is emerging as a key policy challenge for all tiers of government in Australia. Projections of sea-level rise, more intense storms and cyclones, and increased severity of floods and droughts will have profound effects on coastal resources. More critically, the onset of impacts is likely to occur sooner and at larger scales than previously expected, as current growth in greenhouse gas emissions is higher than all scenarios outlined in the Fourth Assessment Report 2007 of the International Panel on Climate Change (IPCC) (Steffen 2009). The impacts of a rapidly changing climate will compound existing risks to vulnerable freshwater and estuarine ecosystems in coastal Australia, and has long-term implications for the services that they provide to communities and the economy (CSIRO 2007; DCC 2009).

For freshwater and estuarine systems, climate change will cause multiple and irreversible change as species either adapt in situ, migrate to suitable new habitat, or perish; resulting in declines or losses of local populations. The capacity of aquatic species to adapt in situ or to shift habitat ranges will depend on the individual species' traits and suitable linkages between available habitats (Allan et al. 2005). In many catchments, further changes to hydrology and water temperature will affect species composition and distribution, and alter inter-species competition and predator-prey interactions, which in turn will affect adaptation responses (Meyer et al. 1999). In 
coastal areas, sea-level rise could force freshwater and estuarine wetlands farther inland if there is suitable space, or to accrete vertically if sediment is available (Richards et al. 2008). However, many endemic estuarine and freshwater species may be unable to disperse to new ranges due to physical barriers and the high fragmentation; thereby increasing the species' vulnerability to extinction.

Planning for these emerging climate impacts on natural systems will require the systematic formulation and implementation of adaptation policies and strategies across multiple scales and sectors (Adger et al. 2005). A primary concept underpinning current adaptation responses is to reduce the vulnerability and increase the adaptive capacity of natural and social systems to respond to changing conditions (IPCC 2007). For ecosystems, policies can be designed to enhance resilience of species to cope with climate change impacts (Fischlin et al. 2007). In many coastal environments in Australia, freshwater and estuarine systems are in a degraded condition, largely as the result of development and land-use changes that involved large-scale vegetation clearing, water extraction and pollution. Adaptation responses could target the management of these nonclimatic stressors with the broader objective of restoring ecosystem function and building resilience to climate change impacts (Steffen et al. 2009).

A widely adopted approach to adaptation involves 'mainstreaming' measures into a range of existing environmental policies, legislation, and planning frameworks. For example, coastal zone planning and management could incorporate measures to respond to sea-level rise and storm surges (Walsh et al. 2004; Nicholls et al. 2007). Water resource planning and management could be adjusted to reduce water stress caused by shifts in rainfall patterns (Kundzewicz et al. 2007). The protected area system could also be expanded with the goal of enhancing the capacity of species to adapt or migrate (Hannah et al. 2002; Mawdsley et al. 2009).

Despite increased mainstreaming of adaptation policy in Australia (Hennessey et al. 2007), there has been limited critical analysis of the capacity and scope of existing policies and legislation to accommodate and effectively address climate change impacts. This is problematic, as current environmental and natural resource management frameworks have broadly failed to limit the decline in ecosystem function, and more importantly, have failed to restore the health and resilience of degraded freshwater and estuarine ecosystems (Beeton et al. 2006). Developers of policy responses for natural systems will also face a number of competing social and economic claims that could limit or potentially stall effective adaptation planning. These competing goals between different social groups and sectors could lead to trade-offs where not all objectives or desired outcomes of adaptation can be achieved in the policy process (Adger et al. 2009). In many localities, governments will need to respond to the potential climate risks to communities and industry sectors, and these responses could take precedence over management of vulnerable aquatic systems (see Knogge et al. 2004). For example, faced with growing pressure to protect property and infrastructure, governments could support and finance construction of sea walls and levees, which could lead to adverse effects on wetland migration (Hulme 2005). More broadly, regional development patterns and economic growth objectives may not adequately take into account climate change impacts and adaptation, further confounding attempts to manage river and wetland habitats and resources. 
This article evaluates adaptation policy responses for freshwater and estuarine systems in tropical coastal Queensland and the barriers to effective adaptation planning. It is argued that, although environmental policy and planning frameworks could incorporate adaptation measures for aquatic systems this response is unlikely to be effective in addressing the scale and severity of projected climate impacts. Many of the constraints that have plagued the development and implementation of existing conservation and natural resource management legislation could also limit the scope of adaptation policy. In many locations, there may be significant opposition to the implementation of policies designed to manage freshwater and estuarine systems under climate change, if these policy options compete with other land uses and urban and regional development pathways. Over the longer term, adaptation policies should aim to manage for dynamic ecosystem change and to avoid further large scale loss of freshwater and estuarine habitats. To achieve this will require that governments prioritise the protection and management of river and wetland systems in adaptation policy formulation, and seek to resolve the systemic constraints to policy implementation.

\section{Overview of tropical Queensland}

Much of the research on climate change policy for coastal aquatic ecosystems has focused on climate change impacts and vulnerability assessment, with limited evaluation of adaptation policy options. This article considers adaptation policy related to river and wetland ecosystems in the coastal catchments of tropical Queensland (Figure 1).

Approximately 30 major rivers and many hundreds of small ephemeral streams drain into the coastal waters of the Great Barrier Reef (GBR) (Furnas 2003). Most major river systems have highly variable flow regimes, dependent on a combination of monsoon weather patterns, the El Niño Southern Oscillation (ENSO), and tropical cyclone intensity and frequency (Hamilton \& Gerkhe 2005). The region also contains nationally important wetlands, including freshwater wetlands located on floodplains of the larger rivers, and marine and inter-tidal wetlands along the coastline (Environment Australia 2001). These rivers, wetlands, marine ecosystems and coral ecosystems of the GBR region form a complex, interlinked mosaic of habitats that support some of the highest diversity of fauna in the world (Sheaves et al. 2007).

The region is comprised of a number of smaller rural settlements, larger cities and service centres located on the coastal floodplains. The economy is dominated by agriculture, mining and mineral processing, and tourism based on the GBR and Wet Tropics World Heritage Areas. Broad-acre agricultural development, whilst increasing regional productivity, has led to the substantial modification of river catchments across the regio (Furnas 2003). Many of the river catchments have highly altered flow regimes and degraded ecosystem function. In the Wet Tropics coastal region, an estimated 80 per cent of freshwater wetlands and riparian vegetation have been drained or cleared for sugar cane cultivation (Johnson et al. 1999). Riparian clearing has impacted on fish and other aquatic fauna by reducing habitat, altering inputs of organic matter and facilitating the invasion of exotic species (Pusey \& Arthington 2003). Altered sediment budgets, the construction of port infrastructure, and land reclamation for marinas and urban development has resulted in a loss of mangrove and intertidal wetland communities (Schaffelke et al. 2005). 


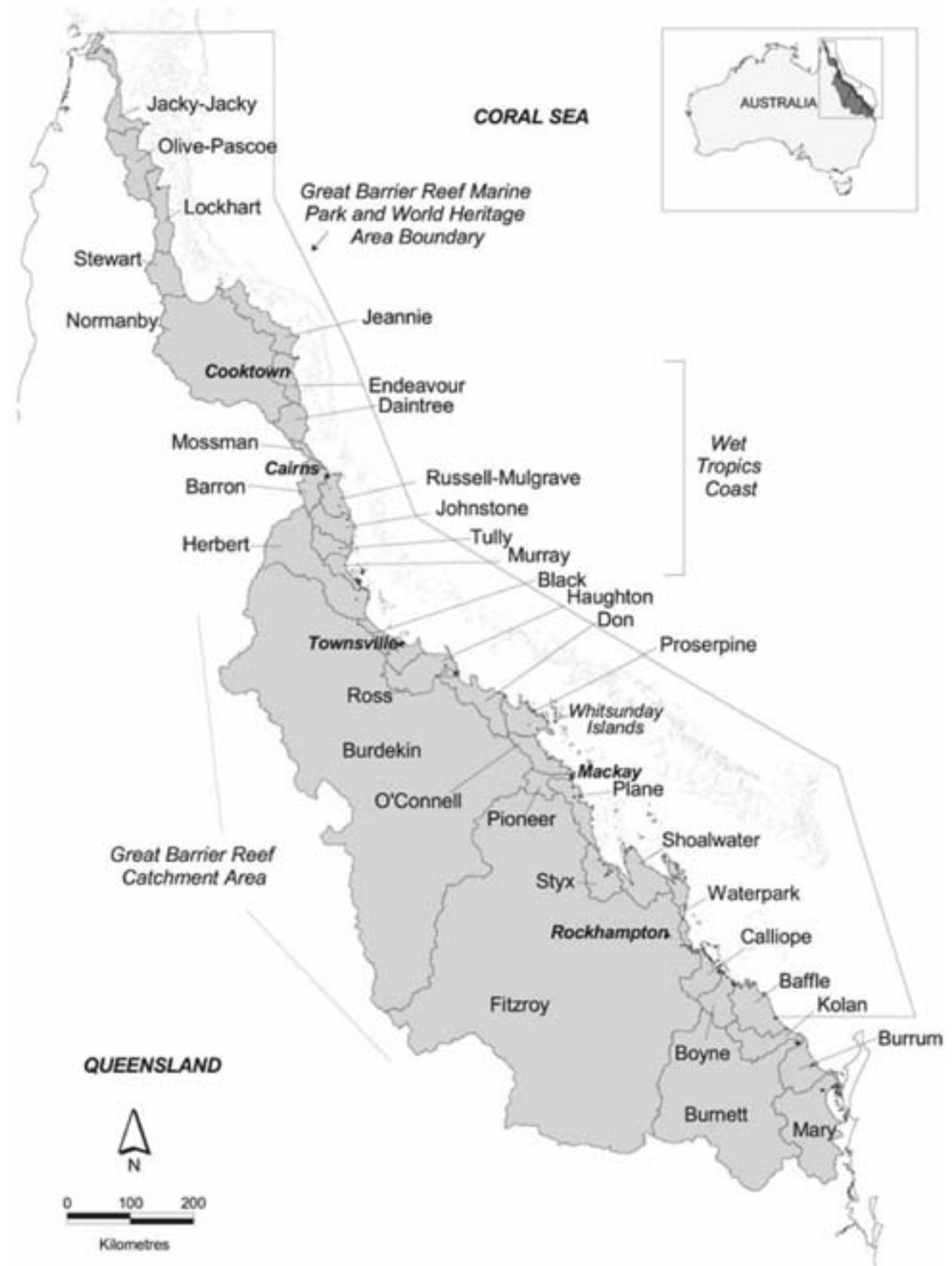

Figure 1 Catchments of northeast Queensland (source: The State of Queensland \& the Commonwealth of Australia 2003)

\section{Projected climate change impacts}

Consistent with global trends, air and sea-surface temperatures have shown a $0.8^{\circ} \mathrm{C}$ warming over northeast Queensland compared to pre-industrial levels (CSIRO 2007). Projections of future change in the region vary depending on the models, timescales and emission scenarios utilised. Average surface temperatures are projected to increase across the study region between 0.8 to $1.2^{\circ} \mathrm{C}$ by 2030 and between 1.5 to $4.2^{\circ} \mathrm{C}$ by 2070 (DERM 2009a). Changes to the ENSO could affect seasonal rainfall variability in coastal regions, but large uncertainties remain in the regional-scale projections. For example, in Far North Queensland by 2030, the winter, summer and autumn rainfall could decrease by one per cent, while spring rainfall could decrease 
by as much as five per cent (DERM 2009a). In addition, evaporation rates are projected to increase between five to ten per cent for many catchments in the region by 2070 (DERM 2009a). Modelling indicates that storm and cyclone intensity over the region is also likely to increase by 2050 , although their frequency is likely to decrease (CSIR0 2007). Intense tropical cyclones and associated storm surges will compound the effects of sea-level rise. Estimates for sea-level rise range between 18$59 \mathrm{~cm}$ by 2100 , with a possible $10-20 \mathrm{~cm}$ additional rise due to the melting of polar ice sheets (IPCC 2007). Modelling for the Cairns area predicts that storm surge heights during extreme cyclone events will range from 2.3 to 2.8 metres by 2050 (McInnes et al. 2003). Flooding is projected to double in magnitude, inundating large areas of intertidal wetlands, low-lying farmland and urban areas.

There are likely to be significant impacts from projected changes to rainfall and sealevel rise on coastal freshwater and estuarine systems in tropical Queensland. Modelling suggests a trend towards more severe but less frequent cyclones and reduced average rainfall for some drier catchments in central Queensland, leading to altered hydrological cycles in rivers that discharge into the GBR lagoon (CSIRO 2007; Lough 2007). In estuaries and tidal wetlands along GBR shoreline, flow changes will affect the delivery of nutrients and sediments, alter salinity concentrations, and have far reaching impacts on habitat availability and the abundance and distribution of species (Sheaves et al. 2007). Changes in sediment delivery could result in either an expansion or reduction of mangrove and saltmarsh habitat (Lovelock \& Ellison 2007). In tropical Australia, the combined effects of sealevel rise, storm surges and shoreline erosion from more intense cyclones, could cause saltwater intrusion into coastal freshwater wetlands (Elliot et al. 1999). For coastal rivers with extensive tidal ranges, saltmarsh and mangrove species may retreat landwards and colonise freshwater wetlands, leading to a reduction in terrestrial habitat diversity (Gilman et al. 2008).

\section{Methods}

To evaluate adaptation policy development in tropical Queensland, primary data were collected using semi-structured in-depth interviews with professionals working in climate change adaptation research and policy in the region. Purposive and snowball sampling techniques were used to identify potential organisations and participants. Thirteen interviews were conducted with senior policy managers, program directors and research scientists from eight organisations, including Commonwealth and Queensland Government agencies, national scientific research organisations, academic research centres, national and state environment nongovernment organisations (NGO), and regional NRM bodies. In addition, data were collected from published government reports, strategies and plans, and from public submissions and websites of industry, business and nongovernment organisations. A combination of expert interviews (Box 1), document analysis and a literature review enabled triangulation of research data to provide accuracy and representativeness ${ }^{1}$.

\footnotetext{
${ }^{1}$ Interviews were not conducted with industry groups; however, policy documents and media statements were used in the analysis to provide a cross section of perspectives. Further research would benefit from interviews with industry groups, landowners and local government representatives.
} 


\section{Semi-structured interview questions:}

- Identify policy and management options for adapting river and wetland ecosystems in coastal tropical Queensland.

- Outline how climate adaptation could be incorporated within existing policies, planning and legislation.

- Discuss the effectiveness of these policies and measures for managing the vulnerability of river and wetland ecosystems to climate change impacts.

- Discuss any limitations/constraints to adaptation policies for river and wetland ecosystems.

- Identify policy options to overcome constraints and resolve tradeoffs in the development and implementation of adaptation policies.

\section{Adaption policy development and implementation}

The majority of interview respondents suggested that mitigation of non-climate change impacts on freshwater and estuarine ecosystems in the region is likely to provide greater benefits than climate change specific policies in reducing vulnerability and increasing resilience to climate change. As many river systems are degraded by habitat loss and water infrastructure, it could be more effective for adaptation policies to focus on reducing land-use impacts and managing or restoring hydrological processes and connectivity in river systems.

A number of existing environmental policy frameworks are designed to manage and respond to non-climate change impacts and, if implemented, could provide broader 'no-regrets' adaptation benefits. There are also a range of specific adaptation policies and management actions that could be applied to assist adaptation of freshwater and estuarine systems. These adaptation responses are often complementary with current biodiversity conservation and natural resource management legislation. Therefore, priority adaptation responses could be readily mainstreamed into existing environmental policy frameworks covering state, regional and local jurisdictions.

\section{Regional and coastal planning}

A review was undertaken of statutory planning instruments and legislation that covers management of wetland and river systems in the GBR region (Table 1). Development and land use adjacent to wetlands and waterways in the Queensland coastal zone is regulated via the Sustainable Planning Act 2009 (Qld) and the Coastal Protection and Management Act 1995 (Qld). In association with these Acts, the Queensland Government has developed general policy guidelines to address projected climate change impacts in the coastal zone through the current State Coastal Management Plan and the State Planning Policy 1/03 - Mitigating the Adverse Impacts of Flood, Bushfire and Landslide ${ }^{2}$.These frameworks include policies on shoreline erosion, flooding hazards, and guidelines for managing coastal freshwater and estuarine ecosystems.

\footnotetext{
2 The State Coastal Management Plan provides a tiered approach to integrating adaptation into regional coastal plans and local planning schemes, including avoiding development in areas vulnerable to sea level rise; planned retreat from rising sea levels; the facility for planning amendments; and asset protection, with a focus on the defence of vulnerable coastal developments
} 
The Queensland Government is reviewing the coastal planning framework and has released a Draft State Coastal Plan 2009 that includes specific adaptation measures. The proposed new planning framework requires 'setbacks' (i.e. development buffers) of between 100 to $200 \mathrm{~m}$ around mapped wetland systems to limit the impacts from urban development. These setbacks are to maintain the functioning of habitat values, and to enable fluctuations in the size and location of coastal wetlands in response to storm-tide inundation and sealevel rise. However, exemptions are permitted for essential infrastructure that can not be located outside wetland areas, and where impacts can not be avoided or mitigated; offsets will be required under the Queensland Government's Environmental Offsets Policy 2008. State and local governments have also commenced integrating specific climate change adaptation policies for freshwater and estuarine ecosystems into regional and local statutory planning frameworks under the Sustainable Planning Act 2009. For example, the Far North Queensland Regional Plan 2009-2031 (DIP 2009) contains explicit measures to manage climate change impacts. The plan specifies that new urban development must be located away from areas with high ecological significance, including mapped or listed wetlands. Wetland habitats should be protected by buffer zones to prevent external impacts from land uses and runoff, and to allow for wetland migration due to sea-level rise and erosion. The plan also requires setbacks and 'water envelopes' (i.e. aquatic buffer zones) to protect ecological values of riparian vegetation. Development is restricted within envelope areas to accommodate flooding and climate change related impacts, such as erosion and changes to channel morphology.

Interview respondents from state government agencies argued that statutory planning frameworks provide a relatively robust mechanism for protecting existing wetlands and rivers from expansion of the urban footprint. Establishing protective vegetation buffers and setbacks, and maintaining riparian connectivity along river corridors, could enhance the adaptive capacity of aquatic ecosystems. However, several respondents from research organisations and environmental NGOs suggested that the current projections used for planning may underestimate the scale of sea-level rise, exposing communities and wetlands to more severe climate hazards. The current proposed urban and industrial development zoning contained in the statutory regional and local plans could result in limited flexibility to respond to higher end emissions scenarios, and longer term impacts. Once housing and infrastructure is constructed, it imposes limits on future adaptation responses.

\section{Water resource planning and management}

The IPCC identified water resource planning and management as an important policy instrument for responding to increasing climatic variability and to greater demands on water resources in a changing climate (Kundzewicz et al. 2007). In Queensland, water resource planning and management under the Water Act 2000 provides a framework to balance human consumption with the environmental flow requirements for aquatic ecosystems (Arthington \& Pusey 2003). Statutory water resource plans are required to apply hydrological modelling and risk frameworks when outlining environmental flow objectives and to protect the health of aquatic ecosystems. 
Table 1 Adaptation policy options and existing policy frameworks

\begin{tabular}{|c|c|c|c|}
\hline Adaptation measure & Impact & Instrument & Status of implementation \\
\hline $\begin{array}{l}\text { Provide space for wetland } \\
\text { migration } \\
\text { Establish development } \\
\text { setbacks and buffer zones } \\
\text { for wetlands and } \\
\text { waterways } \\
\text { Manage retreat for } \\
\text { shoreline erosion and } \\
\text { saltwater intrusion }\end{array}$ & $\begin{array}{l}\text { Sea-level rise } \\
\text { Storm surge } \\
\text { Flooding }\end{array}$ & $\begin{array}{l}\text { Coastal Protection and Management } \\
\text { Act } 1995 \text { (Qld) } \\
\text { Draft State Coastal Plan } \\
\text { Regional coastal plans } \\
\text { Sustainable Planning Act } 2009 \text { (Qld) } \\
\text { Far North Queensland Regional Plan } \\
\text { Local government planning schemes } \\
\text { State Planning Policy 1/03 - Mitigating } \\
\text { the Adverse Impacts of Flood, Bushfire } \\
\text { and Landslide } \\
\text { Temporary State Planning Policy 1/10: } \\
\text { Protecting Wetlands of High Ecological } \\
\text { Significance in Great Barrier Reef } \\
\text { Catchments }\end{array}$ & $\begin{array}{l}\text { New adaptation measures } \\
\text { Setbacks and buffer zones } \\
\text { integrated into planning } \\
\text { schemes } \\
\text { Policies of managed retreat } \\
\text { for shoreline erosion and } \\
\text { flooding }\end{array}$ \\
\hline $\begin{array}{l}\text { Down-scaled regional } \\
\text { flow projections } \\
\text { Water allocation } \\
\text { flexibility } \\
\text { Water efficiency measures }\end{array}$ & $\begin{array}{l}\text { Increased } \\
\text { water stress }\end{array}$ & $\begin{array}{l}\text { Water Act } 2010 \text { (Qld) } \\
\text { Water resource plans } \\
\text { Resource operation plans } \\
\text { Regional water supply strategies } \\
\text { Rural and urban water use efficiency } \\
\text { measures }\end{array}$ & $\begin{array}{l}\text { New adaptation measures } \\
\text { Down-scaled modelling } \\
\text { integrated into water } \\
\text { resource plans }\end{array}$ \\
\hline $\begin{array}{l}\text { Protect and manage } \\
\text { habitat connectivity and } \\
\text { climate change refugia } \\
\text { Protect transition zones } \\
\text { for wetland migration } \\
\text { Protect entire catchments } \\
\text { Manage non-climate } \\
\text { change impacts }\end{array}$ & $\begin{array}{l}\text { Sea-level rise } \\
\text { Floods } \\
\text { Drought } \\
\text { Water } \\
\text { temperature } \\
\text { increases }\end{array}$ & $\begin{array}{l}\text { Environment Protection and } \\
\text { Biodiversity Conservation Act } 1999 \\
\text { (Cwth) } \\
\text { RAMSAR wetlands } \\
\text { Nature Conservation Act } 1992 \text { (QId) } \\
\text { National parks } \\
\text { Nature refuges } \\
\text { Land for wildlife (voluntary) } \\
\text { Coastal Protection and Management } \\
\text { Act } 1995 \text { (QId) } \\
\text { Significant and important wetlands } \\
\text { Fisheries Act } 1994 \text { (Qld) } \\
\text { Fisheries habitat } \\
\text { Wild Rivers Act } 2005 \text { (Qld) } \\
\text { Wild river declarations }\end{array}$ & $\begin{array}{l}\text { Existing policies (no } \\
\text { specific adaptation policies } \\
\text { for rivers and wetlands) }\end{array}$ \\
\hline $\begin{array}{l}\text { Ecosystem restoration } \\
\text { Remove barriers to } \\
\text { wetland and waterway } \\
\text { migration } \\
\text { Increase habitat } \\
\text { connectivity }\end{array}$ & $\begin{array}{l}\text { Sea-level rise } \\
\text { Altered } \\
\text { streamflow } \\
\text { Increased } \\
\text { water } \\
\text { temperature }\end{array}$ & $\begin{array}{l}\text { Queensland Wetlands Program } \\
\text { Great Barrier Reef Wetlands Program } \\
\text { Environmental Offsets Policy (Qld) } \\
\text { NRM Plans }\end{array}$ & $\begin{array}{l}\text { Existing programs (no } \\
\text { specific adaptation policies } \\
\text { for rivers and wetlands) }\end{array}$ \\
\hline
\end{tabular}

Government respondents argued that the current Queensland water resource planning and management framework has adequate provisions to manage climate change impacts and increased water stress. However, respondents from environment NGOs strongly disagreed with this position, arguing that the water resource planning framework does not provide the flexibility to respond to climate change effects on environmental flows. Once allocations and operating guidelines have been set, it is very difficult for regulating authorities to adjust in response to ecosystem needs. Environmental NGOs identified that planning requires greater flexibility to allocate additional water for the environment, such as during extended periods of below average flows, and particularly for stressed and over-allocated river systems. 
A key issue for water resource management in a changing climate is the large uncertainties in the scale of projected changes to precipitation and streamflow at the catchment and sub-catchment scales. Representatives from state government agencies indicated that current uncertainties make it extremely difficult to incorporate climate variation into water resource planning, allocations and management. For the agriculture sector, uncertainty could affect the future security of water entitlements and the capacity of irrigators to adjust to climate change impacts (QFF 2009). In response, the Queensland Government is currently delivering regional, down-scaled projections of water availability to guide water resource planning and allocations (DERM 2009a). There was broad agreement from interviewees that new modelling and improved data would assist in incorporating climate change into water planning and management. Several respondents from scientific research organisations also suggested that down-scaled projections of rainfall and streamflow at the local property scale are needed to inform decision-making and to guide water allocation and use.

\section{Reserve systems}

The design and expansion of protected area systems and legislative frameworks is an important climate change response (Mawdsley et al. 2009), and could be used to protect and manage wetlands (Gilman et al. 2008) and river reaches, and to improve connectivity at the catchment scale. Freshwater, saltmarsh and mangrove wetlands listed as RAMSAR sites or in the Directory of Important Wetlands (e.g. Environment Australia 2001) can gain status under Australian Government legislation (i.e. the Environment Protection and Biodiversity Conservation Act 1999) as a matter of National Environmental Significance for which developments may require impact assessment as part of the approval process.

In Queensland, there is special purpose legislation, such as the Queensland Fisheries Act 1994 (Qld) which protects mangrove and intertidal ecosystems as fisheries habitats, and the Coastal Protection and Management Act 1995 which protects significant coastal wetlands. These mechanisms in combination protect an estimated 1 156553 ha of wetlands in the region, with additional wetlands managed under native vegetation management laws and in national parks and nature refuges (EPA 2008). In May 2010, the Queensland Government introduced Temporary State Planning Policy 1/10: Protecting Wetlands of High Ecological Significance in Great Barrier Reef Catchments. The policy controls development and earthworks within mapped wetlands and adjacent buffer zones, and protects habitat corridors and surface- and ground-water flows (DERM 2010).

The Queensland Government has committed to doubling protected areas statewide, but there is no indication that climate change adaptation criteria for wetlands or rivers will be integrated into reserve designs. Scientist and environmental NGO respondents argued that, in the intensely developed coastal floodplains of the region, protected area planning should integrate adaptation requirements for freshwater and estuarine systems. Reserve designs should aim to increase habitat connectivity along river corridors and to link estuaries with floodplains and upstream catchments. Suitable land should also be set aside adjacent to existing protected areas to enable wetlands to shift across floodplains and along river gradients. Respondents from regional NRM organisations suggested that future reserve systems will need to combine public and 
private conservation frameworks, including extensive off-reserve voluntary conservation programs on private land. Respondents from scientific and environmental NGOs also pointed out that declarations under the Wild Rivers Act 2005 (Qld) provide a relatively strong climate change adaptation tool for river systems. Declarations provide robust protection for river, wetland and floodplain ecosystems and prevent the clearing or draining of wetlands or construction of instream dams and weirs. Several respondents argued that declarations could be used to protect ecosystems that provide important climate change refugia for aquatic species.

\section{Restoration}

Restoration 3of wetlands, streams and riparian zones provides a management option to buffer the effects of climate change on species and ecosystem processes (Brinson 2006; Palmer et al. 2008). A cross-section of respondents suggested that restoring and rehabilitating degraded wetland and riverine areas could improve ecosystem health and the resilience of aquatic species. For example, the removal of barrages and small in-stream weirs could restore flow-related processes and increase the connectivity between river channels, wetlands and estuaries. Restoring hydrological processes will enable wetland and riverine species to move laterally in the floodplain and to disperse along river gradients. The rehabilitation of riparian corridors and weed removal also improves the connectivity between stream habitats and increases shading to enable more tolerant species to adjust to changes in water temperature.

In catchments that discharge into the GBR lagoon, the restoration and management of wetlands and riparian zones is a key objective for improving water quality flowing into marine waters (The State of Queensland \& Commonwealth of Australia 2003). Two programs are underway (the Queensland Wetlands Program and the Great Barrier Reef Coastal Wetlands Protection Program) that provide funding for onground works. A number of pilot wetland rehabilitation projects have commenced in the region. These projects include the protection of riparian areas and wetlands through fencing and erosion control, weed removal, and replanting vegetation. Several respondents from scientific, environmental and NRM organisations questioned whether small-scale restoration projects would be effective for managing large-scale climate impacts on aquatic ecosystems, such as rapid sea- level rise and more severe cyclones. An example was provided of Cyclone Larry, which in 2006 severely affected a number of wetland and riverine revegetation sites in the Wet Tropics region, stripping and destroying areas of restored vegetation. On the other hand, large scale restoration projects may be more resilient to disturbance, but these will be resource intensive and could prove difficult to implement along extensive sections of the coastline.

\section{Constraints on effective adaptation}

Respondents identified a range of constraints on existing statutory planning, natural resource management and biodiversity conservation frameworks to address climate change adaptation requirements of rivers and wetlands. These constraints are multiple,

\footnotetext{
${ }^{3}$ Restoration can be defined as the process of assisting the recovery of ecosystems that are degraded or have been removed (Lake et al. 2007).
} 
complex and derive from broader processes of economic development and failures by policy and governance arrangements to manage environmental degradation caused by current patterns of land use and development. Several respondents identified that, although there is a range of existing legislation to protect and manage aquatic ecosystems and water resources, these mechanisms are often poorly implemented and enforced by government agencies. Many wetland and river systems continue to be degraded by urban development, agricultural and industry activities, with the result that condition of wetlands and river systems across the region continues to decline (EPA 2008). If existing government policies have proven inadequate to address the broader impacts from development on freshwater and estuarine resources, then they may also lack the capacity to alleviate more extreme climate change impacts.

Respondents identified that, along the coastal plain, intensely-developed urban areas are likely to cause pervasive barriers to integrating adaptation measures through statutory planning schemes. In particular, property and infrastructure located in lowlying areas - such as on beach fronts, floodplains and adjacent to waterways - will create significant problems. A legacy of development zoning in the region has resulted in residential housing and infrastructure situated in areas vulnerable to flooding, sea- level rise and higher rates of erosion. As climate change is a relatively new issue, adequate measures were not integrated into planning schemes 20 years ago. Local councils have to deal with both existing development in highly exposed areas, and approvals for new housing and infrastructure that have been built into existing planning schemes.

Under Queensland legislation, local and state governments are also liable for claims of compensation if development rights are removed and for insurance claims for damage to development located in high-risk storm and flood zones. This increased risk of flood damage to property and critical infrastructure could lead to engineering solutions becoming a high priority for combating sea-level rise and flooding. In many areas, the further construction of flood protection levees and tidal barrages could restrict the migration of wetland species inland. Raising seawalls and extending rock armouring could exacerbate erosion of beachfronts and mudflats, leading to permanent inundation and the loss of intertidal and coastal habitats altogether. Respondents from research and Australian Government agencies argued that the construction of seawalls along extensive sections of the coastline is maladaptive and not a feasible long-term solution for the region.

There are also likely to be significant barriers that could restrict implementation of policies in rural areas for the purposes of adaptation, such as protected area systems and planning controls for managed shoreline retreat. Representatives from research and NRM organisations identified that low elevation land that may accommodate wetland transitions are likely to presently contain sugar cane farms or rural residential areas. In many such areas, landowners may be unwilling to support conservation or land and wetland restoration efforts if this results in a loss of productive land or increases flood exposure. Representatives from government agencies argued that state and local governments are unlikely to support policies that propose large-scale resumption of farmland, particularly if there is strong opposition from landowners. Even with broad stakeholder support for conservation and adaptation, governments are unlikely to provide sufficient resources and funding to purchase land and restore wetlands and river channel systems along the entire length of the coastline. 
Governments also face longer-term problems with managing water resources and increased water stress from altered rainfall and riverflow patterns. In addition, projected population growth and proposed expansion of mining and agricultural sectors will increase water demand across a number of catchments in the region (DNRW 2006). These problems with reliability and longer-term water security will drive greater competition for available water resources. In response to growing demands in the region, the Queensland Government has developed regional water supply strategies and implemented water efficiency programs and infrastructure upgrades to reduce system leakage in urban and rural areas. However, the strategies also propose large-scale water supply infrastructure, including five new dams, and a number of smaller weirs and off-stream storages. Research scientists and representatives from environmental NGOs argued that new water supply infrastructure will disrupt ecosystem processes and increase the vulnerability of aquatic ecosystems and species. As one scientist noted, endemic fish species with restricted habitat ranges are at a high risk of extinction from dam construction, particularly if the catchments are already degraded by vegetation clearing, impoundments and water extraction.

All respondents interviewed identified that a key barrier is the availability of science and technical information to guide the adaptation planning and decision-making process. For example, adaptation responses in urban areas are currently constrained by the need for local-scale projections that identify areas vulnerable to flooding and sea-level rise. In rural floodplains, there is a lack of research and detailed mapping that could guide planning for dynamic changes to river and wetland systems. Although more detailed information could assist in identifying climate change impacts and vulnerability, there is likely to remain significant uncertainty in climate projections. In particular, there is a limited capacity to predict decadal and longerterm climatic effects on rainfall and sea-level rise (Hulme et al. 2009). There also remain large irreducible uncertainties in climate change understanding that result from the complexity of the global climate system and future greenhouse emission trajectories (Dessai et al. 2009). Moreover, more detailed climate projections and data are unlikely to resolve some of the critical policy trade-offs between managing vulnerable rivers and wetlands and meeting regional development and growth objectives.

\section{Resolving trade-offs}

Many of the constraints on adaptation will need to be overcome if policy is to limit the impacts and increase the adaptive capacity of freshwater and estuarine systems. Respondents from environmental NGOs and NRM bodies argued that, as a priority, governments should work with industry and landowners to implement and enforce existing legislation and policies designed to protect and manage wetland and riverine resources. Where policies and legislation lack sufficient powers to prevent degradation and loss of habitat, there is a need for stronger and more stringent regulations and incentives. For example, comprehensive protection of river floodplain systems on agricultural land is required across the GBR catchments to manage ecosystem impacts from drainage, modification and water extraction. An important component of new legislation and regulations is to include ongoing monitoring and program assessment to determine if policy and management interventions have been 
successful Respondents from research organisations suggested that, for some species and ecosystems with very low resilience to climate change and other impacts, there may be limited value in undertaking remedial activities designed to increase adaptive capacity. In this context, policy-makers may need to prioritise wetland and river systems when investing resources in protection and management so that investments actually deliver increased resilience and adaptive capacity. If this approach is to be adopted, governments and the broader community may need to accept further loss of freshwater and estuarine habitats from some areas, as a trade-off for greater protection and management of habitats in other, more strategic locations.

Several respondents suggested that, if mainstreaming adaptation into existing policy proves inadequate, then governments and stakeholders will need to develop new policy frameworks that address the underlying problems caused by regional processes of urban, industrial and rural development. These policies should prioritise the adaptive needs of ecosystems and seek to eliminate unsustainable land use and development practices. For freshwater and estuarine ecosystems, this means developing appropriate planning and resource management instruments that can manage for dynamic ecosystem change at the landscape scale. A practical application of this approach is to develop instruments that plan for potential impacts from higherend emission scenarios, such as sea-level rise above one metre, more severe floods, and reduced water reliability. As uncertainty is likely in all climate projections, planning will need to factor in high variation and the potential for abrupt shifts in the climate system. More critically, this planning may need to progress with inadequate data and science to guide the decision-making process.

\section{Conclusion}

Mainstreaming adaptation into existing biodiversity conservation and natural resource management policy has become the primary mechanism of governments to implement adaptation responses to projected short-term climate change impacts. In many policy domains, it is a relatively easy approach as it often involves only minor adjustments to policy instruments and can be implemented through the regular policy and legislative review process. However, many existing policies are not framed to address a range of larger scale, longer term and more severe impacts from climate change on freshwater and estuarine systems in tropical Queensland. Using existing policy frameworks to meet the challenge posed by climate change could lead to the same systemic problems that have pervaded the management of non- climate change threats. There is also likely to be strong opposition to policies designed to assist species and ecosystems to adapt to change if these policies conflict with existing and future urban development and land use. Governments will face growing demands to protect housing, infrastructure and rural land from increasing climate change hazards that may result in maladaptive responses that further reduce ecosystem resilience.

Although balancing competing interests is conceptually appealing, in reality, there will be trade-offs between protecting and managing the adaptive capacity of rivers and wetlands and meeting the demands from communities and industry. If avoiding further catastrophic loss of species and ecosystems is the longer-term goal, then policy-makers may need to prioritise conservation needs of rivers and wetlands above other types of land use and resource exploitation. As a first step, governments should consider restricting the expansion of urban development, infrastructure and industry 
on low elevation land at risk from longer-term climate change hazards, and more suitable land options sourced. Likewise, governments should shift away from development and infrastructure projects that damage ecosystem and species resilience, such as the further construction of large-scale water supply infrastructure.

An option to address competing policy demands involves governments and stakeholders developing specific adaptation policies and legislation that takes a systematic approach to managing multiple climate change and other human impacts. Governments also need to consider new or strengthened governance arrangements to enable all stakeholders to develop an holistic and integrated approach to adaptation planning and policy-making in the region. These processes could provide opportunities to develop innovative, new policy solutions that can meet the adaptation needs of rivers and wetlands and reduce climate risk to communities and industry. For example, in the extensive coastal floodplains of tropical Queensland, mangrove wetlands, estuarine deltas and river floodplain systems may provide the only feasible landscape-scale management approach to combat rapidly rising seas, larger floods and severe cyclones. As Day et al. (2007) showed, river and coastal deltaic systems can provide critical protection against severe cyclonic and storm surge events, and restoration and management of these ecosystems could increase resilience and provide a relatively robust and long-term climate change defence system. Such policy approaches will provide multiple benefits, but require significant further research and innovation in the design and scale of the interventions. Further research is also required into policy frameworks and policy-making processes to overcome some of the pervasive constraints to adaptation planning for rivers and wetlands in coastal Australia.

\section{References}

Adger, WN, Arnell, NW \& Tompkins, EL 2005, 'Successful adaptation to climate change across scales', GlobalEnvironmental Change, vol. 15, pp. 77-86.

Adger, WN, Dessai, S, Goulden, M, Hulme, M, Lorenzoni, I, Nelson, DR, Naess, LO, Wolf, J \& Wreford, A 2009, 'Are there social limits to adaptation to climate change?', Climatic Change, vol. 93, pp. 335-354.

Allan, JD, Palmer, M \& Poff, NL 2005, 'Climate change and freshwater ecosystems', in TE Lovejoy \& L Hannah (eds), Climate change and biodiversity, Yale University Press, New Haven, Connecticut, USA, pp. 274-290.

Arthington, AH \& Pusey, BH 2003, 'Flow restoration and protection in Australian rivers', River Research andApplications, vol. 19, pp. 377-395.

Beeton, RJS, Buckley, KI, Jones, GJ, Morgan, D, Reichelt, RE \& Trewin, D (Australian State of the Environment Committee) 2006, Australia State of the Environment 2006, independent report to the Australian Government Minister for the Environment and Heritage, Department of the Environment and Heritage, Canberra.

Brinson, M 2006, 'Consequences for wetlands of a changing global environment', in DP Batzer \& RR Sharitz (eds), Ecology of freshwater and estuarine wetlands, University of California Press, Berkeley, California, USA, pp. 436-461.

CSIRO (Commonwealth Scientific and Industrial Research Organisation) 2007, 
Climate change in Australia: technical report 2007, CSIRO, Aspendale, Victoria. Day Jr, JW, Boesch, DF, Clariain, EJ, Kemp, GP, Laska, SB, Mitsch, WJ, Orth, K, Mashriui, H, Reed, DJ, Shabman, L, Simenstad, CA, Streever, BJ, Twilley, RR, Watson, CC, Wells, JT \& Whigham, DF 2007, 'Restoration of the Mississippi Delta: lessons from Hurricanes Katrina and Rita', Science, vol. 315, pp. 16791684.

DCC (Department of Climate Change) 2009, Climate change risks to Australia's coasts: a first pass national assessment, Australian Government, Canberra, viewed 10 January 2010,

<http://www.climatechange.gov.au/ /media/publications/coastline/cc-risksfull-report.ashx>.

DERM (Department of Environment and Resource Management) 2009a, Climate $Q$ : towards a greenerQueensland, Queensland Government, Brisbane, viewed 23 November 2009, <http://www.climatechange.qld.gov.au/_data/assets/pdf_file/0020/24068/ClimateQ_ Report_web_FINAL_2009>.

DERM (Department of Environment and Resource Management) 2009b, Draft Queensland coastal plan 2009, Queensland Government, Brisbane, viewed 23 November 2009, 〈http://www.derm.qld.gov.au/coastalplan/>.

DERM (Department of Environment and Resource Management) 2010, Temporary State Planning Policy 1/10: Protecting Wetlands of High Ecological Significance in Great Barrier Reef Catchments, Queensland Government, Brisbane, viewed 15 September 2010 , <http://www.derm.qld.gov.au/wildlife-ecosystems/ecosystems/pdf/wetlandsspp.pdf $>$

Dessai, S, Hulme, M, Lempert, R \& Pielke Jr, RA 2009, 'Do we need better predictions to adapt to a changing climate?', EOS, vol. 90, pp. 111-112.

DIP (Department of Infrastructure and Planning) 2009, Far North Queensland regional plan 2009-2031, QueenslandGovernment, Brisbane, viewed 23 November 2009, <http:// www.dip.qld.gov.au/regionalplanning/regional-plan-3.html $>$.

DNRW (Department of Natural Resources and Water) 2006, Central Queensland water supply strategy, QueenslandGovernment, Rockhampton, viewed 20 June 2008, <http://www.cq.water.strategy.qld.gov.au/docuemtnation/ cqrwss_report_dec06/.pdf>.

Elliot, I, Finlayson, CM \& Waterman, P 1999, 'Predicted climate change, sea level rise and wetlands management in the Australian wet-dry tropics', Wetlands Ecology and Management, vol. 7, pp. 63-81.

Environment Australia 2001, A directory of important wetlands in Australia, third edition, Commonwealth Government, Canberra.

EPA (Environment Protection Agency) 2008, State of the environment Queensland 2007, EPA, Brisbane, viewed 10 January 2010, <http://www.derm.qld.gov.au/environmental_management/state_of the env ironment/state_of_the_environment_queensland_2007/state_of the environ 
ment_quee nsland_2007_pdf.html>.

Fischlin, A, Midgeley, GP, Proce, JT, Leemans, R, Gopal, B, Turley, C, Rounsevell, MDA, Dube, OP, Tarazona, J \& Velichko, AA 2007,

'Ecosystems, their properties, goods and services', in ML Parry, OF Canziani, JP Palutikof, PJ van der Linden \& CE Hanson (eds), Climate change 2007: impacts, adaptation and vulnerability, contribution of Working Group II to the Fourth Assessment Report of the Intergovernmental Panel on Climate Change, Cambridge University Press, Cambridge, pp. 211-272.

Furnas, M 2003, Catchments and corals: terrestrial runoff to the Great Barrier Reef, Australian Institute of Marine Science, Townsville, Queensland.

Gilman, EL, Ellison, J, Duke, N \& Field, C 2008, 'Threat to mangroves from climate change and adaptation options: a review', Aquatic Botany, vol. 89, pp. 237-250.

Hamilton, SK \& Gehrke PC 2005, 'Australian tropical river systems: current understanding and critical knowledge gaps for sustainable management', Marine and Freshwater Research, vol. 56, pp. 243-252.

Hannah, L, Midgley, GF, Lovejoy, T, Bond, WJ, Bush, M, Lovett, JC, Scott, D \& Woodward, FI 2002, 'Conservation of biodiversity in a changing climate', Conservation Biology, vol.16, pp. 264-268.

Hennessey, KB, Bates, BC, Harvey, N, Howden, SM, Hughes, L, Slinger, J \& Warrick R, 2007, 'Australia and New Zealand', in ML Parry, OF Canziani, JP Palutikof, PJ van der Linden \& CE Hanson (eds), Climate change 2007: impacts, adaptation and vulnerability, contribution of Working Group II to the Fourth Assessment Report of the Intergovernmental Panel on Climate Change, Cambridge, pp. 507-540.

Hulme, M, Pielke Jr, R \& Dessai, S 2009, 'Keeping prediction in perspective', Nature Reports Climate Change, vol. 3, November 2009, viewed 14 April 2010, 〈http://www.nature.com/climate/2009/0911/full/climate.2009.110.html>.

Hulme, PE 2005, 'Adapting to climate change: is there scope for ecological management in the face of a global threat?', Journal of Applied Ecology, vol. 42, pp. $784-794$.

IPCC (Intergovernmental Panel on Climate Change) 2007, 'Summary for policymakers', in ML Parry, OF Canziani, JP Palutikof, PJ van der Linden \& CE Hanson (eds), Climate change 2007: impacts, adaptation and vulnerability, contribution of Working Group II to the Fourth Assessment Report of the Intergovernmental Panel on Climate Change, Cambridge University Press, Cambridge, pp. 7-22.

Johnson, AKI, Ebert, SP \& Murray, AE 1999, 'Distribution of coastal freshwater wetlands and riparian forest in the Herbert River catchment and implications for management of catchments adjacent to the Great Barrier Reef Marine Park', Environmental Conservation, vol. 26, pp. 229-235.

Knogge, T, Schirmer, M \& Schuchardt, B 2004, 'Landscape scale socio-economics of sea-level rise', Ibis, vol. 146, suppl. 1, pp. 11-17.

Kundzewicz, KW, Mata, LJ, Arnell, NW, Doll, Kabat P, Jiminez, B, Miller, 
KA, Oki, T, Sen, Z \& Shiklomanov, A 2007,

'Freshwater resources and their management', in ML Parry, OF Canziani, JP Palutikof, PJ van der Linden \& CE Hanson (eds), Climate change 2007: impacts, adaptation and vulnerability, contribution of Working Group II to the Fourth Assessment Report of the International Panel on Climate Change, Cambridge University Press, Cambridge, pp. 174-210.

Lake, PS, Bond, N \& Reich, P 2007, 'Linking ecological theory with stream restoration', Freshwater Biology, vol. 52, pp. 597- 615.

Lough, J, 2007, 'Climate and climate change on the Great Barrier Reef ', in JE Johnson \& PA Marshall (eds), Climate change and the Great Barrier Reef, Great Barrier Reef Marine Park Authority, Townsville \& Australian Greenhouse Office, Townsville, pp. 15-50.

Lovelock, CE \& Ellison, J 2007, 'Chapter 9: vulnerability of mangroves and tidal wetlands of the Great Barrier Reef to climate change', in JE Johnson \& PA Marshall (eds), Climate change and the Great Barrier Reef, Great Barrier Reef Marine Park Authority, Townsville \& and Australian Greenhouse Office, Townsville, pp. 238-269.

Mawdsley, JR, O’Malley, R \& Ojima, DS 2009, 'A review of climate-change adaptation strategies for wildlife management and biodiversity conservation', Conservation Biology, vol. 23, pp. 1080-1089.

McInnes, KL, Walsh, KJE, Hubbert, GD \& Beer, T 2003, 'Impact of sea level rise and storm surges on a coastalcommunity', Natural Hazards, vol. 30, pp. 187-207.

Meyer, JL, Sale, MJ, Mulholland, PJ \& Poff, NL 1999, 'Impacts of climate change on aquatic ecosystem functioning and health', Journal of American Water Resources Association, vol. 35, pp. 1373-1386.

Nicholls, RJ, Wong, PP, Burkett, VR, Codignotto, JO, Hay, JE, McLean, RF, Ragoonaden, S \& Woodroffe, CD 2007, 'Coastal systems and low lying areas', in ML Parry, OF Canziani, JP Palutikof, PJ van der Linden \& CE Hanson (eds), Climate change 2007: impacts, adaptation and vulnerability, contribution of Working Group II to the Fourth Assessment Report of the International Panel on Climate Change, Cambridge University Press, Cambridge, pp. 315-356.

Palmer, MA, Reidy Liermann, CA, Nilsson, C, Florke, M, Alcamo, J, Lake, PS \& Bond, N 2008, 'Climate change and the world's river basins: anticipating management options', Frontiers in Ecology and the Environment, vol. 6, pp. 115 .

Pusey, BJ \& Arthington, AH 2003, 'Importance of the riparian zone to the conservation and management of freshwater fish: a review with special emphasis on tropical Australia', Marine and Freshwater Research, vol. 54, pp. 1-16.

QFF (Queensland Farmers Federation) 2009, A farmers guide to climate change in Queensland, QFF, Brisbane, viewed 23 March 2010, <http://www.qff.org.au/files/_system/Document/ClimateChangeReport_lowres(1). pdf $>$.

Richards, JA, Mokrech, M, Berry, PM \& Nicholls, RJ 2008, 'Regional assessment 
of climate change impacts on coastal and fluvial ecosystems and the scope for adaptation', Climatic Change, vol. 90, pp. 141-167. Schaffelke, B, Mellors, J \& Duke, NC 2005, 'Water quality in the Great Barrier Reef region: responses of mangrove, seagrass and macroalgal communities', Marine Pollution Bulletin, vol. 51, pp. 279-296.

Sheaves, M, Brodie, J, Brooke, B, Dale, P, Lovelock, CE, Waycott, M, Gherke, P, Johnston, R \& Baker, R 2007, 'Chapter19: vulnerability of coastal and estuarine habitats in the Great Barrier Reef to climate change', in JE Johnson \& PA Marshall (eds), Climate change and the Great Barrier Reef, Great Barrier Reef Marine Park Authority, Townsville \& Australian Greenhouse Office, Townsville, pp. 594-618.

Steffen, W 2009, Climate change 2009: faster change and more serious risks, Department of Climate Change, Canberra, viewed 23 November 2009, http://www.climatechange.gov.au/ /media/publications/science/cc-

faster_change.ashx.

Steffen, W, Burbidge, AA, Hughes, L, Kitching, R, Lindenmayer, D, Musgrave, W, Stafford Smith, M \& Werner, P 2009, Australia's biodiversity and climate change: a strategic assessment of the vulnerability of Australia's biodiversity to climate change, report to the National Resource Management Ministerial Council, CSIRO Publishing, Collingwood, Victoria.

The State of Queensland \& the Commonwealth of Australia 2003, Reef water quality protection plan: for catchments adjacent to the Great Barrier Reef World Heritage Area, Queensland Department of Premier and Cabinet, Brisbane, viewed 25 May 2010, http://www.reefplan.qld.gov.au/library/ pdf/reefplan.pdf.

Walsh, KJE, Betts, H, Church, J, Pittock, AB, McInnes, KL, Jacket, DR \& Mcdougall, TJ 2004, 'Using sea level rise projections for urban planning in Australia', Coastal Research, vol. 20, pp. 586-599 